\title{
Gambaran karakteristik pneumonia pada anak yang dirawat di ruang perawatan intensif anak RSUP Prof. Dr. R. D. Kandou Manado periode $2013-2015$
}

\author{
${ }^{1}$ Christian T. Kaunang \\ ${ }^{2}$ Ari L. Runtunuwu \\ ${ }^{2}$ Audrey M. I. Wahani
}

\author{
${ }^{1}$ Kandidat Skripsi Fakultas Kedokteran Universitas Sam Ratulangi Manado \\ ${ }^{2}$ Bagian/SMF Ilmu Kesehatan Anak Fakultas Kedokteran \\ Universitas Sam Ratulangi Manado \\ Email: yamato.kira64@yahoo.com
}

\begin{abstract}
Pneumonia is an acute respiratory tract infection that became a public health problem in the world due to the high mortality in infants and toddlers. This study was aimed to describe the characteristics of pneumonia in children treated at the pediatric intensive care unit Prof. Dr. R. D. Kandou Hospital Manado in 2013 - 2015. This was a descriptive retrospective study with a cross sectional design. Subjects were all children suffering from pneumonia hospitalized at the pediatric intensive care unit Prof. Dr. R. D. Kandou Hospital Manado in 2013 - 2015. There were 158 cases consisted of 62 patients in 2013, 74 patients in 2014, and 22 patients in 2015. Most of them were males (88 patients) and at the age group $<1$ year (108 patients). The average pulse was 194.75 beats/minute, the average breathing rate was 60.4 breaths/minute, and the average body temperature was $37.8^{\circ} \mathrm{C}$. The majority showed retraction at the subcostal area (148 patients), crackles (142 patients), inaudible wheezing (147 patients), clinical symptom as shortness of breath (148 patients), chest X-ray as infiltrate (151 patients), laboratory tests as the average value of hemoglobin was $11.3 \mathrm{~g} /$ $\mathrm{dL}$, the average hematocrit was $33.3 \%$, the average of leukocyte count was $45,293 / \mathrm{mm} 3$, and the average of platelet count was $364.437 / \mathrm{mm} 3$.
\end{abstract}

Keywords: pneumonia, children, characteristic features

\begin{abstract}
Abstrak: Pneumonia merupakan penyakit infeksi saluran pernapasan akut yang menjadi masalah kesehatan di dunia karena angka kematiannya sangat tinggi pada bayi dan balita. Penelitian ini bertujuan untuk mengetahui gambaran karakteristik pneumonia pada anak yang dirawat di ruang perawatan intensif RSUP Prof. Dr. R. D. Kandou Manado pada tahun 2013-2015. Jenis penelitian ialah deskriptif retrospektif dengan desain potong lintang. Subjek penelitian ialah semua anak yang menderita pneumonia dirawat di ruang perawatan intensif anak di Bagian Ilmu Kesehatan Anak RSUP Prof. Dr. R. D. Kandou Manado selang Januari 2013 - Desember 2015. Terdapat 158 kasus dengan rincian 62 pasien pada tahun 2013, 74 pasien pada tahun 2014, dan 22 pasien pada tahun 2015. Didapatkan anak yang menderita pneumonia paling banyak pada jenis kelamin laki-laki ( 88 pasien) dan kelompok usia <1 tahun (108 pasien). Nilai rerata denyut nadi didapatkan 194,75 kali/menit, laju pernapasan 60,4/menit, dan suhu badan $37,8^{\circ} \mathrm{C}$. Sebagian besar kasus memperlihatkan retraksi di bagian subkostal (148 pasien), ronki (142 pasien), tanpa wheezing (147 pasien), gejala klinis sesak nafas (148 pasien), gambaran foto toraks adanya infiltrat (151 pasien). Pemeriksaan laboratorium mendapatkan rerata nilai hemoglobin $11,3 \mathrm{~g} / \mathrm{dL}$, hematokrit $33,3 \%$, hitung leukosit $45.293 / \mathrm{mm} 3$, dan hitung trombosit $364.437 / \mathrm{mm} 3$.
\end{abstract}

Kata kunci: pneumonia, anak, gambaran karakteristik 
Penyakit infeksi saluran pernapasan akut (ISPA) khususnya pneumonia masih merupakan penyakit utama penyebab kesakitan dan kematian bayi dan balita. ${ }^{1}$ ISPA adalah radang akut saluran pernapasan atas maupun bawah yang disebabkan oleh infeksi jasad renik atau bakteri, virus, maupun riketsia, tanpa atau disertai radang parenkrim paru. ${ }^{2}$ Penyakit ini dapat menimbulkan berbagai spektrum penyakit dari penyakit tanpa gejala sampai penyakit parah dan mematikan tergantung pada patogen penyebabnya, faktor lingkungan, dan pejamu. Data 10 besar penyakit terbanyak pada pasien rawat jalan Rumah Sakit di Indonesia tahun 2009, menempatkan infeksi saluran napas bagian atas pada urutan pertama dengan total kasus sebanyak $488.794 .^{3}$

Pneumonia adalah infeksi akut yang mengenai jaringan paru-paru (alveoli) dan mempunyai gejala batuk, sesak nafas, ronki, dan infiltrat pada foto rontgen. Terjadinya pneumonia pada anak sering kali bersamaan dengan terjadinya proses infeksi akut disebut bronkopneumonia. ${ }^{1}$ Dalam pelaksanaan pengendalian penyakit ISPA semua bentuk pneumonia (baik pneumonia maupun bronkopneumonia), disebut "Pneumonia" saja. ${ }^{3}$

Pneumonia merupakan masalah kesehatan di dunia karena angka kematiannya sangat tinggi, tidak saja di negara berkembang tetapi juga di Negara maju seperti Amerika, Kanada dan NegaraNegara Eropa lainya. Di Amerika pneumonia merupakan penyebab kematian nomor satu setelah kardiovaskuler dan TBC. Kasus pneumonia ditemukan paling banyak menyerang anak balita. ${ }^{2}$ Tahun 2007 1,2 juta orang di Amerika Serikat dirawat di rumah sakit dengan pneumonia dan lebih dari 52.000 orang meninggal akibat penyakit ini. Di daerah Eropa dan Amerika Utara kejadian pneumonia 34-40 kasus per 1.000 anak, kebanyakan kasus pneumonia pada anak usia prasekolah yaitu, empat bulan sampai lima tahun. Di dunia setiap 20 detik seorang anak meninggal akibat pneumonia dan setiap tahun diperkirakan lebih dari 2 juta balita meninggal karena pneumonia (1 balita/15 detik) dari 9 juta total kematian balita. ${ }^{4}$

Berdasarkan data WHO dan Departemen Kesehatan Republik Indonesia tahun 2008, pneumonia yang merupakan salah satu jenis ISPA ialah penyebab paling banyak kematian balita di dunia dan juga di Indonesia. ${ }^{5}$ Berdasarkan data WHO tahun 2015 pneumonia menyumbang $15 \%$ dari seluruh kematian anak di bawah 5 tahun, menewaskan sekitar 922000 anak-anak. ${ }^{6}$ Berdasarkan hasil Survei Kesehatan Rumah Tangga (SKRT) tahun 2001, angka kematian balita akibat penyakit sistim pernapasan adalah 4,9/1.000 balita, yang berarti terdapat sekitar 5 dari 1.000 balita yang meninggal setiap bulan akibat pneumonia, atau berarti tiap tahun terdapat 140.000 balita yang meninggal akibat pneumonia. Data ini juga berarti bahwa rata-rata 1 anak balita Indonesia meninggal akibat pneumonia dalam setiap 5 menit.

Melihat dari banyaknya angka kematian balita akibat pneumonia, maka pneumonia patut menjadi suatu masalah dunia yang harus diatasi, namun $\mathrm{Di}$ Universitas Sam Ratulangi belum pernah dilakukan penelitian mengenai gambaran karakteristik pneumonia pada anak yang dirawat di ruang intensif RSUP Prof. Dr. R. D. Kandou Manado pada tahun 2013 2015. Hal ini yang menjadi latar belakang penelitian ini.

\section{METODE PENELITIAN}

Jenis penelitian yang dilaksanakan ialah deskriptif retrospektif dengan desain potong lintang.. Populasi penelitian ialah semua anak yang dirawat di ruang perawatan intensif di Bagian Ilmu Kesehatan Anak FK Unsrat RSUP Prof. Dr. R. D. Kandou Manado selang Januari 2013 - Desember 2015. Data rekam medis pasien yang digunakan ialah pasien dengan pneumonia dibawah usia 1 tahun dan usia 1 tahun sampai 18 tahun yang dirawat di ruang perawatan intensif RSUP Prof. Dr. R. D. Kandou Manado pada bulan Januari 2013 sampai dengan Desember 2015. Pengambilan sampel dilakukan dengan metode total sampling 
Kriteria inklusi ialah semua pasien anak pneumonia yang dirawat di ruang perawatan intensif RSUP Prof. Dr. R. D. Kandou Manado periode tahun 2013-2015 yang memiliki rekam medik yang lengkap. Kriteria eksklusi ialah semua pasien anak pneumonia yang dirawat di ruang perawatan intensif RSUP Prof. Dr. R. D. Kandou Manado periode tahun 2013-2015 yang tidak memiliki hasil ekspertisi foto toraks. Variabel penelitian yaitu, usia, jenis kelamin, pemeriksaan fisik, gambaran klinis, gambaran foto toraks, gambaran hasil laboratorium.

\section{HASIL PENELITIAN}

Penelitian ini dilakukan dengan mengambil data sekunder pada pasien anak yang dirawat di RSUP Prof. Dr. R. D. Kandou Manado mulai bulan Agustus 2016 sampai dengan November 2016 dan didapatkan 158 pasien dengan rinician 62 pasien pada tahun 2013, 74 pasien pada tahun 2014, dan 22 pasien pada tahun 2015.

\section{Karakteristik usia subyek penelitian}

Frekuensi tertinggi terdapat pada kelompok usia bayi yaitu pada usia <1 tahun $(68,4 \%)$, diikuti kelompok usia anak dini (1-3 tahun) (24,7\%), kemudian diikuti kelompok usia prasekolah (>3-6 tahun) $(4,4 \%)$ dan yang frekuensi terendah terdapat pada kelompok usia sekolah $(>6$ 18 tahun) (2,5\%) (Tabel 1).

Tabel 1. Karakteristik penderita pneumonia pada anak berdasarkan kelompok usia

\begin{tabular}{ccc}
\hline Usia & (n) & $\mathbf{( \% )}$ \\
\hline $\begin{array}{c}\text { Masa bayi } \\
(<1 \text { tahun) }\end{array}$ & 108 & 68,4 \\
Masa anak dini & 39 & 24,7 \\
$\quad(1-3$ tahun) & & \\
Masa prasekolah (>3-6 tahun) & 7 & 4,4 \\
Masa sekolah \\
$(>6-18$ tahun)
\end{tabular}

\section{Karakteristik jenis kelamin subyek penelitian}

Pada penelitian ini didapatkan frekuensi penderita pneumonia anak tertinggi terdapat pada jenis kelamin laki- laki $(55,7 \%)$, dan sisanya terdapat pada jenis kelamin perempuan yaitu $(44,3 \%)$ (Tabel 2).

Tabel 2. Karakteristik penderita pneumonia pada anak berdasarkan jenis kelamin.

\begin{tabular}{ccc}
\hline Jenis kelamin & $(\mathrm{n})$ & $(\%)$ \\
\hline Laki-laki & 88 & 55,7 \\
Perempuan & 70 & 44,3 \\
\hline
\end{tabular}

\section{Karakteristik pemeriksaan fisik tanda- tanda vital subyek penelitian}

Hasil dari analisis data univariat menggunakan SPSS versi 22 didapatkan nilai rerata nadi $131,9 /$ menit, pernapasan 60,4/menit, dan suhu $37,8^{\circ} \mathrm{C}$ (Tabel 3).

Tabel 3. Karakteristik penderita pneumonia pada anak berdasarkan pemeriksaan fisik.

\begin{tabular}{cc}
\hline Pemeriksaan fisik & Anak $(\mathbf{n}=\mathbf{1 5 8})$ \\
\hline Nadi, rerata (SB) /menit & $194,7(2,8)$ \\
Pernapasan, rerata (SB) & $60,4(6,9)$ \\
/menit & $37,8(0,4)$ \\
Suhu, rerata $(\mathrm{SB}){ }^{\circ} \mathrm{C}$ & \\
\hline
\end{tabular}

\section{Karakteristik pemeriksaan fisik retraksi}

Frekuensi tertinggi terdapat pada pasien yang mengalami retraksi subkostal (93,7\%), diikuti yang mengalami retraksi interkostal $(80,4 \%)$, retraksi sifoid $(29,7 \%)$, retraksi suprasternal $(17,1 \%)$. dan frekuensi terendah terdapat pada yang mengalami retraksi epigastrium $(1,3 \%)$ (Tabel 4).

Tabel 4. Karakteristik penderita pneumonia pada anak berdasarkan pemeriksaan fisik retraksi

\begin{tabular}{ccc}
\hline Retraksi & (n) & $(\mathbf{\%})$ \\
\hline Subkostal & 148 & 93,7 \\
Interkostal & 127 & 80,4 \\
Suprasternal & 27 & 17,1 \\
Sifoid & 47 & 29,7 \\
Epigastrium & 2 & 1,3 \\
\hline
\end{tabular}

\section{Karakteristik pemeriksaan fisik ronki}

Pada penelitian ini didapatkan frekuensi tertinggi pada penderita pneumonia anak yang dirawat di ruang perawatan intensif ialah yang ditemukan ronki saat pemeriksaan fisik auskultasi 
$(89,9 \%)$, dan sisanya yang tidak ditemukannya ronki $(10,1 \%)$ (Tabel 5).

Tabel 5. Karakteristik penderita pneumonia pada anak berdasarkan pemeriksaan fisik ronki

\begin{tabular}{ccc}
\hline Ronki & $(\mathrm{n})$ & $(\%)$ \\
\hline Ada & 142 & 89,9 \\
Tidak ada & 16 & 10,1 \\
\hline
\end{tabular}

\section{Karakteristik pemeriksaan fisik wheezing}

Pada penelitian ini didapatkan frekuensi tertinggi pada penderita pneumonia anak yang dirawat di ruang perawatan intensif ialah ditemukannya wheezing saat pemeriksaan fisik auskultasi (7\%), dan sisanya yang tidak ditemukannya wheezing (93\%) (Tabel 6).

Tabel 6. Karakteristik penderita pneumonia pada anak berdasarkan pemeriksaan fisik wheezing

\begin{tabular}{ccc}
\hline Wheezing & $(\mathrm{n})$ & $(\%)$ \\
\hline Ada & 11 & 7 \\
Tidak ada & 147 & 93 \\
\hline
\end{tabular}

\section{Karakteristik gambaran klinis subyek penelitian}

Frekuensi tertinggi pada gambaran klinis penelitian ini terdapat pada gejala klinis sesak yaitu sebesar 148 pasien (93,7\%), diikuti dengan batuk sebesar 145 pasien $(91,8 \%)$, dan demam yaitu sebesar 140 pasien $(88,6 \%)$, dan frekuensi yang terendah adalah sianosis yaitu sebesar 6 pasien $(3,8 \%)$ (Tabel 7).

Tabel 7. Karakteristik penderita pneumonia pada anak berdasarkan gambaran klinis

\begin{tabular}{ccc}
\hline Gambaran klinis & (n) & $\mathbf{( \% )}$ \\
\hline Sesak & 148 & 93,7 \\
Batuk & 145 & 91,8 \\
Demam & 140 & 88,6 \\
Muntah & 13 & 8,2 \\
Sianosis & 6 & 3,8 \\
Kejang & 14 & 8,9 \\
BAB cair & 21 & 13,3 \\
Pilek & 20 & 12,7 \\
\hline
\end{tabular}

\section{Karakteristik gambaran foto toraks subyek penelitian}

Pada penelitian ini dilakukan pemeriksaan foto toraks dan didapatkan frekuensi tertinggi dari hasil foto toraks adalah gambaran dengan adanya infiltrat yaitu sebesar 151 pasien $(95,6 \%)$, dan sisanya adalah gambaran dengan adanya perselubungan yaitu sebesar 138 pasien $(87,3 \%)$ (Tabel 8).

Tabel 8. Karakteristik penderita pneumonia pada anak berdasarkan gambaran foto toraks

\begin{tabular}{ccc}
\hline Foto toraks & $(\mathrm{n})$ & $(\%)$ \\
\hline Infiltrat & 151 & 95,6 \\
Perselubungan & 138 & 87,3 \\
\hline
\end{tabular}

\section{Karakteristik gambaran hasil laboratorium subyek penelitian}

Median hemoglobin 11,35 g/dL dengan nilai hemoglobin terendah $5,7 \mathrm{~g} / \mathrm{dL}$ dan nilai hemoglobin tertinggi 19,1 g/dL. Median hematokrit 33,5\% dengan nilai hematokrit terendah $17,7 \%$ dan nilai hematokrit tertinggi 58\%. Median leukosit $40.200 / \mathrm{mm}^{3}$ dengan nilai leukosit terendah $1.700 / \mathrm{mm}^{3}$ dan nilai leukosit tertinggi $61.300 / \mathrm{mm}^{3}$. Median tombosit $356.500 / \mathrm{mm}^{3}$ dengan nilai trombosit terendah $44.000 / \mathrm{mm}^{3}$ dan nilai trombosit tertinggi 1.096.000/ $\mathrm{mm}^{3}$ (Tabel 9).

Tabel 9. Karakteristik penderita pneumonia pada anak berdasarkan gambaran hasil laboratorium.

\begin{tabular}{|c|c|}
\hline Hasil laboratorium & Anak $(n=158)$ \\
\hline $\begin{array}{l}\text { Hemoglobin, rerata } \\
\text { (SB) g/Dl }\end{array}$ & $11,3(1,8)$ \\
\hline $\begin{array}{c}\text { Hematokrit, rerata }(\mathrm{SB}) \\
\%\end{array}$ & $33,3(5,4)$ \\
\hline $\begin{array}{l}\text { Leukosit, rerata }(\mathrm{SB}) \\
\qquad / \mathrm{mm}^{3}\end{array}$ & $45293(12437,5)$ \\
\hline $\begin{array}{c}\text { Trombosit, rerata (SB) } \\
/ \mathrm{mm}^{3}\end{array}$ & $364436,7(180241)$, \\
\hline
\end{tabular}

\section{BAHASAN \\ Karakteristik sampel usia}

Dari data sekunder pada pasien anak yang dirawat di RSUP Prof. Dr. R. D. Kandou Manado mulai bulan Agustus 2016 sampai dengan November 2016, didapatkan 
hingga 158 data yang diberikan Tim Rekam Medis RSUP Prof. Dr. R. D. Kandou Manado, dengan rinician 62 pasien pada tahun 2013, 74 pasien pada tahun 2014, dan 22 pasien pada tahun 2015.

Frekuensi penderita pneumonia anak pada penelitian ini dibagi menjadi 4 kelompok usia berdasarkan klasifikasi menurut UKK Tumbuh Kembang Pediatri Sosial (Tabel 1). ${ }^{12}$ Frekuensi tertinggi terdapat pada kelompok usia bayi yaitu pada usia <1 tahun $(68,4 \%)$, diikuti kelompok usia anak dini $(24,7 \%)$, kelompok usia prasekolah $(4,4 \%)$, dan kelompok usia sekolah $(2,5 \%)$. Penelitian ini sejalan dengan penelitian yang dilakukan oleh Nurjannah et al. ${ }^{10}$ yang mendapatkan bahwa usia $<1$ tahun merupakan usia anak terbanyak yang menderita pneumonia. Monita ${ }^{13}$ juga menemukan pada 178 kasus pneumonia bahwa usia terbanyak anak yang menderita pneumonia terdapat pada usia 2 bulan sampai <1 tahun $(43,8 \%)$. Faktor usia merupakan salah satu faktor risiko kematian pada balita yang menderita pneumonia. Risiko untuk terkena pneumonia lebih besar pada balita yang berusia $<2$ tahun dibandingkan dengan balita yang berusia $>2$ tahun. Hal ini dikarenakan usia $<2$ tahun merupakan masa rentan bagi balita untuk tertular penyakit pneumonia sebab daya tahan tubuh balita masih rendah dan sistem saluran napas yang belum berfungsi sempurna. ${ }^{9}$

\section{Karakteristik sampel jenis kelamin}

Pada penelitian ini didapatkan frekuensi penderita pneumonia anak tertinggi terdapat pada jenis kelamin lakilaki $(55,7 \%)$, dan sisanya terdapat pada jenis kelamin perempuan $(44,3 \%$ ) (Tabel 2). Penelitian ini sejalan dengan penelitian yang dilakukan oleh Kurniawan et al. ${ }^{14}$ yang menlaporkan bahwa lebih banyak pasien anak yang menderita pneumonia berjenis kelamin laki-laki. Balakrishnan ${ }^{15}$ juga menemukan dari 83 kasus anak, pada anak laki-laki lebih banyak menderita pneumonia daripada perempuan $(67,5 \%){ }^{15}$ Menurut Depkes RI 2004, dikatakan bahwa jenis kelamin merupakan salah satu faktor risiko terjadinya penyakit pneumonia. Sunyataningkamto mengatakan jensi kelamin anak laki-laki merupakan faktor risiko yang memengaruhi kesakitan pneumonia. Hal ini disebabkan diameter saluran pernapasan anak laki-laki lebih kecil dibandingkan anak perempuan atau adanya perbedaan dalam daya tahan tubuh anak laki-laki dan perempuan. ${ }^{16}$

\section{Karakteristik sampel pemeriksaan fisik}

Pada penelitian ini didapatkan pemeriksaan fisik pada anak yang menderita pneumonia (Tabel 3). Hasil penelitian ini dibagi menjadi 3 kategori, diukur menurut batasan yang sesuai dengan klasifikasi dari American Heart Association (AHA) 2012. ${ }^{17}$ Hasil analisis data univariat menggunakan SPSS versi 22 mendapatkan nilai rerata denyut nadi $194,75 \mathrm{kali} /$ menit, nilai median yaitu sebesar $195 \mathrm{kali} / \mathrm{menit}$, nilai tertinggi $199 \mathrm{kali} / \mathrm{menit}$, dan nilai terendah $191 \mathrm{kali} / \mathrm{menit}$. Pada pemeriksaan fisik laju pernapasan, didapatkan nilai rerata yaitu sebesar $60,4 / \mathrm{kali}$ menit, nilai median yaitu sebesar $59 \mathrm{kali} / \mathrm{menit}$, nilai tertinggi 88 kali/menit, dan nilai terendah $55 \mathrm{kali} / \mathrm{menit}$. Pada pemeriksaan fisik suhu badan, didapatkan nilai rerata suhu badan yaitu sebesar $37,8^{\circ} \mathrm{C}$ median yaitu sebesar $37,6^{\circ} \mathrm{C}$, nilai tertinggi $39,9^{\circ} \mathrm{C}$, dan nilai terendah $37,6^{\circ} \mathrm{C}$. Penelitian Nurjannah et al. ${ }^{10}$ mendapat nilai rerata yang hampir sama dengan penelitian ini yaitu didapatkan rata-rata laju napas sekitar $60 \mathrm{kali} / \mathrm{menit}$ dan denyut nadi $147,2 \mathrm{kali} / \mathrm{menit}$, juga didapatkan rata-rata suhu badan $38{ }^{\circ} \mathrm{C} . .^{10}$ Palafox et al. ${ }^{18}$ menyatakan bahwa takipnu pada pneumonia mempunyai nilai sensitivitas $74 \%$ dan spesifisitas $67 \%$ dibandingkan dengan foto toraks sebagai baku emas, maka dinyatakan bahwa takipnu dapat digunakan sebagai tanda klinis dalam menegakkan diagnosis pneumonia. Suhu yang tinggi pada umumnya terjadi pada infeksi yang disebabkan oleh bakteri. ${ }^{10}$ Dari data pemeriksaan fisik retraksi (Tabel 4) didapatkan bahwa retraksi yang paling sering terjadi ialah retraksi subkostal 
$(93,7 \%)$, diikuti yang mengalami retraksi interkostal $(80,4 \%)$, retraksi sifoid $(29,7 \%)$, retraksi suprasternal $(17,1 \%)$, retraksi epigastrium (1,3\%). Penelitian yang dilakukan di Padang mendapatkan hasil ditemukan retraksi dinding dada sebanyak 153 kasus $(86 \%){ }^{13}$ Penelitian yang sama juga dilakukan oleh Nurjannah et al. ${ }^{10}$ dan mendapatkan hasil bahwa ditemukan retraksi dinding dada sebanyak 95 kasus (66\%). Penelitian ini sesuai dengan kepustakaan yang ada yang menyatakan bahwa pada pneumonia, retraksi jaringan antara tulang rusuk (retraksi subkostal dan interkostal) lebih sering terjadi dari pada retraksi suprakostal. ${ }^{11}$

Pada penelitian ini (Tabel 5), didapatkan frekuensi tertinggi pada penderita pneumonia anak yang dirawat di ruang perawatan intensif ialah yang ditemukannya ronki saat pemeriksaan fisik auskultasi $(89,9 \%)$, dan sisanya yang tidak ditemukannya ronki $(10,1 \%)$. Penelitian ini sejalan dengan penelitian yang dilakukan oleh Nurjannah et al. ${ }^{10}$ yang mendapatkan hasil pemeriksaan fisik auskultasi bahwa adanya ronki pada penderita pneumonia yaitu sebanyak 133 kasus $(92,4 \%)$. Pada penelitian Monita ${ }^{13}$ didapatkan pasien yang terdengar ronki pada saat dilakukan pemeriksaan fisik auskultasi yaitu sebanyak 163 kasus (91,6\%). Ronki berasal dari bronki yang lebih besar atau trakea dan mempunyai bunyi yang berpuncak lebih rendah dari sonor. Bunyi-bunyi tersebut terdengar pada pasien yang mengalami penurunan sekresi. Ronki dapat disebabkan oleh hilangnya stabilitas jalan napas perifer yang kolaps pada saat ekspirasi. Tekanan inspirasi yang tinggi menyebabkan terjadinya pemasukan udara cepat ke dalam unit-unit udara distal. Hal ini menyebabkan pembukaan yang cepat dari alveoli dan bronkus kecil atau bronkus sedang yang mengandung sekret pada bagian-bagian paru yang berdeflasi sampai volume residu. ${ }^{19}$

Pada penelitian ini (Tabel 6), didapatkan yang ditemukannya wheezing saat pemeriksaan fisik auskultasi yaitu sebesar 11 pasien (7\%), dan sisanya yang tidak ditemukannya wheezing yaitu sebesar 147 pasien (93\%). Penelitian ini mirip dengan penelitian yang dilakukan oleh Nurjannah et al. ${ }^{10}$ yang menyatakan bahwa ditemukannya wheezing pada pemeriksaan fisik auskultasi pada anak yang menderita pneumonia yaitu sebanyak 13 kasus (9\%). Penelitian yang dilakukan di Padang mendapatkan hasil bahwa ditemukan wheezing sebanyak 26 kasus $(14,6 \%){ }^{13}$ Wheezing pada anak diatas 5 tahun mungkin terkait dengan bakteri atipikal (Mycoplasma atau Chlamydia) dan pneumonia virus serta tidak mungkin karena penyebab bakteri lainnya. ${ }^{20}$ Wheezing merupakan suara nafas seperti musik yang terjadi karena adanya penyempitan jalan udara atau tersumbat sebagian. Obstruksi seringkali terjadi sebagai akibat adanya sekresi atau edema. Bunyi yang sama juga terdengar pada asma dan banyak proses yang berkaitan dengan bronkokonstriksi. Wheezing dapat berasal dari bronki dan bronkiolus yang kecil. Bunyi yang terdengar mempunyai puncak suara tinggi dan bersiul. ${ }^{37}$

\section{Karakteristik sampel gambaran klinis}

Dari data karakteristik penderita pneumonia berdasarkan gambaran klinis (Tabel 7) didapatkan frekuensi tertinggi pada gejala klinis sesak $(93,7 \%)$, diikuti dengan batuk $(91,8 \%)$, demam $(88,6 \%)$, dan sianosis $(3,8 \%)$.

Penelitian ini tidak sejalan dengan peneltian yang dilakukan Dani et al. ${ }^{21}$ yang mendapatkan hasil bahwa gejala klinis terbanyak pada 51 kasus penderita pneumonia anak ialah batuk $(91 \%)$. Pada penelitian Monita ${ }^{13}$ juga mendapatkan hasil yang berbeda dengan penelitian saya oleh karena pada penelitiannya didapatkan hasil bahwa gejala klinis terbanyak pada 178 kasus penderita pneumonia anak adalah demam yaitu sebanyak 165 pasien $(92,7 \%){ }^{13}$

Demam juga merupakan gejala yang paling sering terjadi, suhu yang tinggi pada umumnya terjadi pada infeksi yang disebabkan oleh bakteri. ${ }^{10}$ Manifestasi klinis sesuai dengan kriteria WHO untuk 
pneumonia yaitu batuk, demam, takipnu, peningkatan usaha napas, napas cuping hidung, dan hipoksia didukung dengan pemeriksaan penunjang foto toraks. ${ }^{22}$ Mardjanis membagi gambaran klinis pneumonia menjadi 2 kelompok. Pertama, gejala umum misalnya demam, sakit kepala, maleise, nafsu makan kurang, gejala gastrointestinal seperti mual, muntah dan diare. Kedua, gejala respiratorik seperti batuk, napas cepat (tachypnoel fast breathing), napas sesak (retraksi dada/chest indrawing), napas cuping hidung, air hunger dan sianosis. Hipoksia merupakan tanda klinis pneumonia berat. Anak pneumonia dengan hipoksemia 5 kali lebih sering meninggal dibandingkan dengan pneumonia tanpa hipoksemia. ${ }^{8}$ Perbedaan yang didapatkan dari masing-masing penelitian bergantung dari alloanamnesis dari ibu dimana biasanya ibu lebih peka terhadap gejala demam dibandingkan dengan gejala lainnya dan pada penelitian ini didapatkan gejala paling banyak adalah sesak dikarenakan pada penelitian ini diambil sampel pasien yang dirawat di ruang perawatan intensif. Untuk masuk di ruang perawatan intensif mempunyai beberapa indikasi diantaranya yaitu hipoksemia, pasien yang menderita penyakit dasar jantung paru, sumbatan jalan nafas, atau pasien penyakit jantung, penyakit paru terminal disertai komplikasi penyakit akut berat dimana pada data yang saya teliti didapatkan pasien yang memiliki ciri-ciri yang sama.

\section{Karakteristik sampel gambaran foto toraks}

Pemeriksaan foto toraks merupakan pemeriksaan penting untuk mendiagnosis penyakit pneumonia. Pada penelitian ini (Tabel 8) dilakukan pemeriksaan foto toraks dan didapatkan frekuensi tertinggi dari hasil foto toraks ialah gambaran adanya infiltrat $(95,6 \%)$, dan sisanya ialah gambaran adanya perselubungan $(87,3 \%)$. Penelitian yang dilakukan oleh Monita ${ }^{13}$ pada 178 kasus mendapatkan bahwa gambaran foto toraks yang paling sering ditemukan ialah gambaran adanya infiltrat
(96,6\%). Eldrian juga mendapatkan hasil yang sejalan dengan penelitian ini. ${ }^{13}$ Hasil penelitian Eldrian mengenai gambaran foto toraks menemukan bahwa gambaran yang paling sering ialah adanya infiltrat $(73,21 \%)$. Berbeda dengan pemeriksaan laboratorium jumlah leukosit, pemeriksaan radiologis tidak dapat menunjukkan perbedaan nyata antara infeksi virus dengan bakteri. Seringkali panas dan takipneu sudah timbul sebelum terlihat perubahan pada foto rontgen thoraks. Foto toraks umumnya akan kembali normal setelah 3-4 minggu. ${ }^{13}$

\section{Karakteristik sampel gambaran hasil laboratorium}

Pada penelitian ini didapatkan gambaran hasil laboratorium pada anak yang menderita pneumonia (Tabel 9). Hasil dari penelitian ini dibagi menjadi 3 kategori yang diukur menurut batasan yang sesuai dengan klasifikasi dari Texas Children's Hospital Clinical Laboratory 2011. ${ }^{23}$ Hasil analisis data univariat menggunakan SPSS versi 22 mendapatkan nilai rerata hemoglobin 11,3 g/dL, nilai median yaitu sebesar 11,35 $\mathrm{g} / \mathrm{dL}$, nilai tertinggi 19,1 $\mathrm{g} / \mathrm{dL}$, dan nilai terendah 5,7 g/dL. Pada pemeriksaan laboratorium hematokrit, didapatkan nilai rerata yaitu sebesar 33,3\%, nilai median yaitu sebesar $33,5 \%$, nilai tertinggi $58 \%$, dan nilai terendah $17,7 \%$. Pada pemeriksaan laboratorium leukosit, didapatkan nilai rerata yaitu sebesar $45.293 / \mathrm{mm}^{3}$, median yaitu sebesar $40.200 / \mathrm{mm}^{3}$, nilai terendah $1.700 / \mathrm{mm}^{3}$, dan nilai tertinggi $61.300 / \mathrm{mm}^{3}$. Pada pemeriksaan laboratorium trombosit, didapatkan nilai rerata yaitu sebesar $364.437 / \mathrm{mm}^{3}$, nilai median yaitu sebesar $356.500 / \mathrm{mm}^{3}$, nilai tertinggi $1.096 .000 / \mathrm{mm}^{3}$, dan nilai terendah $44.000 / \mathrm{mm}^{3}$. Pada penelitian yang dilakukan oleh Nurjannah et al. ${ }^{10}$ didapatkan rata-rata hasil laboratorium pada penderita pneumonia yaitu pada hemoglobin $10,9 \mathrm{~g} / \mathrm{dL}$, hematokrit $32,5 \%$, leukosit $14.051 / \mathrm{mm}^{3}$, dan trombosit $361.638 / \mathrm{mm}^{3}$. Penelitian yang dilakukan Michelow $^{24}$ juga menemukan nilai leukosit 
yang tertinggi rata-rata pada kasus pneumonia idalah $16.000 / \mathrm{mm}^{3}$ yang disebabkan oleh bakteri. Monita ${ }^{13}$ menyatakan bahwa nilai leukosit pada pasien pneumonia anak yang paling sering adalah anak yang memiliki nilai leukosit dalam batas normal. Penelitian ini tidak sejalan dengan penelitian yang dilakukan oleh Jufri ${ }^{25}$ yang mendapatkan hasil bahwa pada penderita pneumonia lebih sering didapatkan peningkatan hemoglobin yaitu sebanyak 26 pasien $(40,62 \%)$ dari 64 pasien yang diteliti. Guven et al. mendapatkan neonatus yang menderita pneumonia memiliki hemoglobin yang lebih tinggi. ${ }^{25}$ Menurut penelitian Baum ${ }^{26}$ didapatkan penurunan angka hematokrit sampai $50 \%$ dapat terjadi pada minggu ke 2-3 dari perjalanan penyakit pneumonia. Winarsih menyatakan bahwa peningkatan kadar hematokrit dapat terjadi pada keadaan edema hebat yang akan terjadi pengeluaran cairan dari pembuluh darah ke jaringan ekstravaskuler. $^{27}$ Menurut Dawson dan Whittow penurunan nilai hematokrit dapat disebabkan oleh kerusakan eritrosit, penurunan produksi eritrosit atau dapat juga dipengaruhi oleh jumlah dan ukuran eritrosit. ${ }^{28}$ Menurut Swenson jika terjadi peningkatan jumlah eritrosit pada temperatur lingkungan yang rendah akan meningkatkan nilai hematokrit bila volume darah tetap, sebaliknya bila pada temperatur lingkungan yang tinggi akan menurunkan nilai hematokrit sebagai akibat dari berkurangnya jumlah eritrosit. ${ }^{28}$ Pada penelitian mengenai trombosit yang dilakukan oleh Jufri $^{25}$ didapatkan nilai trombosit pada penderita pneumonia anak yang paling sering adalah anak yang memiliki nilai trombosit normal.

\section{SIMPULAN}

Dari hasil penelitian terhadap anak yang didiagnosis dengan pneumonia dapat disimpulkan bahwa mayoritas ialah anak berusia <1 tahun, berjenis kelamin lakilaki, gambaran foto toraks adanya infiltrat, gejala yang tersering yaitu sesak, adanya retraksi di bagian subkostal, adanya ronki, tanpa wheezing disertai dengan pemeriksaan fisik tanda-tanda vital dengan rerata denyut nadi $194,75 \mathrm{kali} /$ menit,. laju pernapasan $60,4 /$ menit, suhu badan $37,8^{\circ} \mathrm{C}$, dan hasil laboratorium ditemukan rerata hemoglobin 11,3 g/dL, hematokrit 33,3\%, hitung leukosit $45.293 / \mathrm{mm}^{3}$, dan hitung trombosit $364.437 / \mathrm{mm}^{3}$.

\section{SARAN}

Untuk pengembangan ilmu diperlukan penelitian lebih lanjut dengan desain kohort prospektif pada anak berusia 1-18 tahun agar mendapatkan faktor-faktor risiko yang berperan dalam kejadian pneumonia.

Pemeriksaan kultur darah perlu dilakukan untuk mencari kuman penyebab pneumonia agar bisa diketahui piñatalaksanaan lanjutan yang akan diberikan.

Perlu dilakukann penyuluhan kepada masyarakat mengenai gejala-gejala dan halhal yang dapat menyebabkan terjadinya pneumonia.

\section{DAFTAR PUSTAKA}

1. Sugihartono, Nurjazuli. Analisis faktor risiko kejadian pneumonia pada balita di wilayah kerja Puskesmas Sidorejo Kota Pagar Alam. Jurnal Kesehatan Lingkungan Indonesia. 2012;11:82-6.

2. Sigalingging G. Karakteristik penderita penyakit pneumonia pada anak di Ruang Merpati II Rumah Sakit Umum Herna Medan. Darma Agung. 2011:6978.

3. Sundari S, Pratiwi, Khairudin. Perilaku tidak sehat ibu yang menjadi faktor resiko terjadinya ispa pneumonia pada balita. Jurnal Pendidikan Sains. 2014;2:141-6.

4. Mokoginta D. Faktor risiko kejadian pnemonia pada anak balita di wilayah kerja Puskesmas Sudiang Kota Makassar [Skripsi]. Makassar: Universitas Hasanuddin; 2013.

5. Nasution K, Sjahrullah MAR, Brohet KE, Wibisana KA, Yassien MR, Ishak LM, et al. Infeksi saluran napas akut pada balita di Daerah Urban Jakarta. Sari Pediatri. 2009;11:223-7.

6. WHO. Pneumonia. 2016 Sep. [cited 31 Agustus 2016]. Available from: http://www.who.int/mediacentre/factsh eets/fs331/en/.

7. Sulistyoningsih H, Rustandi R. Faktor-faktor 
yang berhubungan dengan kejadian ispa pada balita di Wilayah Kerja Puskesmas DTP Jamanis Kabupaten Tasikmalaya tahun 2010. Prosiding Seminar Nasional "Peran Kesehatan Masyarakat dalam Pencapaian MDG's di Indonesia"; 2011 Apr 12. FKM UNSIL, c2011.

8. Buletin Jendela Epidemiologi. Pneumonia Balita. [cited 31 Agustus 2016]. Available from: http://www.depkes. go.id/download.php?file=download/pus datin/buletin/buletin-pneumonia.pdf.

9. Puspitasari DE, Syahrul F. Faktor risiko pneumonia pada balita berdasarkan status imunisasi campak dan status asi eksklusif. Jurnal Berkala Epidemiologi. 2015;3:69-81.

10. Nurjannah, Sovira N, Anwar S. Profil pneumonia pada anak di RSUD Dr. Zainoel Abidin, studi retrospektif. Sari Pediatri. 2012;13:324-7.

11. Ahmad NAJ. Profil pasien pneumonia komunitas di Rumah Sakit Umum Daerah Cengkareng tahun 2013-2014 [Skripsi]. Jakarta: Universitas Islam Negeri Syarif Hidayatullah; 2015.

12. Soetjiningsih. Tumbuh kembang anak (2nd ed). Jakarta: EGC, 1982; p. 10.

13. Monita O, Yani FF, Lestari Y. Profil pasien pneumonia komunitas di Bagian Anak RSUP dr. M. Djamil Padang Sumatera Barat. Jurnal Kesehatan Andalas. 2015;4:218-24.

14. Kurniawan Y, Indriyani SAK. Karakteristik pasien pneumonia di Ruang Rawat Inap Anak Rumah Sakit Umum Provinsi Nusa Tenggara Barat. CDK-191. 2012;39:196-7.

15. Balakrishnan RK. Gambaran pneumonia pada anak di RSUP Haji Adam Malik Medan periode Januari 2011-Desember 2013 [Skripsi]. Medan: Universitas Sumatera Utara; 2014.

16. Hartati S, Nurhaeni N, Gayatri D. Faktor risiko terjadinya pneumonia pada anak balita. Jurnal Keperawatan Indonesia. 2012;15:13-20.

17. Emedicinehealth. Pediatric vital signs. 2016 Juli 12. [cited 11 November 2016]. Available from: http://www. emedicinehealth.com/pediatric_vital_si gns/article_em.htm

18. Palafox M, Guiscafré H, Reyes H, Muñoz O, Martínez H. Diagnostic value of tachypnoea in pneumonia defined radiologically. Arch Dis Child. 2000;82:41-5.

19. Medicinesia. Bunyi nafas. 2011 Juli 1. [cited 11 November 2016]. Available from: http://www.medicinesia.com/kedoktera n-dasar/respirasi/bunyi-nafas/

20. Gereige RS, Laufer PM. Pneumonia. 2013 Oktober. [cited 11 November 2016]. Available from: http://pedsinreview. aappublications.org/content/34/10/438

21. Dani, Widyarto B, Mairi M. Gambaran karakteristik balita penderita pneumonia di Rumah Sakit Immanuel Bandung tahun 2013. Jurnal Kesehatan. 2013:1-7.

22. Gessman LM, Rappaport DI. Approach to community-acquired pneumonia in children. Hospital Physician. 2009:1-5

23. Gregory, Andropoulos DB. Gregory's Pediatric Anesthesia (5th ed). Blackwell Publishing, 2012; p. 130014.

24. Michelow IC, Olsen K, Lozano J, Rollins NK, Duffy LB, Ziegler $T$, et al. Epidemiology and clinical characteristics of community-acquired pneumonia in hospitalized children. Pediatrics. 2004;113:701-7.

25. Jufri J. Profil pneumonia neonatus yang dirawat di RSUP Prof. Dr. R. D. Kandou Manado [Skripsi]. Manado: Universitas Sam Ratulangi; 2013.

26. Lubis HM. Pneumonia mikoplasma [Skripsi]. Medan: Universitas Sumatera Utara; 2005.

27. Ali AS, Ismoyowati, Indrasanti D. Jumlah eritrosit, kadar hemoglobin dan hematokrit pada berbagai jenis itik lokal terhadap penambahan probiotik dalam ransum. 2013;1:1001-13.

28. Rosita A, Mushawwir A, Latipudin D. Status hematologis (eritrosit, hematokrit, dan hemoglobin) ayam petelur fase layer pada temperature humidity index yang berbeda. 2015:110. 